\title{
Penguasaan Konsep Siswa pada Materi Fluida Statis Dalam Pembelajaran STEM Disertai E-Formative Assessment
}

\author{
Zahrotul Ula Irma ${ }^{1}$, Sentot Kusairi ${ }^{1}$, Lia Yuliati ${ }^{1}$ \\ ${ }^{1}$ Pendidikan Fisika-Universitas Negeri Malang
}

\begin{tabular}{l} 
INFO ARTIKEL \\
\hline Riwayat Artikel: \\
Diterima: $27-12-2019$ \\
Disetujui: $19-06-2020$ \\
\hline
\end{tabular}

\section{Kata kunci:}

mastery of concepts; Problem-based STEM; penguasaan konsep; STEM berbasis masalah;

E-formative assessment

\begin{abstract}
ABSTRAK
Abstract: This study aims to explore students' conceptual understanding of static fluid in STEM with e-formative assessment learning. The study uses embedded experimental design methods. It involved 30 students of XI grade high school in Sidoarjo. The pretest and posttest instruments consisted of 10 reasoning multiple chooise questions with reliability is 0.629 . Wilcoxon test results is $p=.000$ with an average posttest higher than pretest shows that there is significant difference between students' conceptual understanding of before and after learning. The effect size value is 0.88 . Students' conceptual understanding of each indicator is also discussed.

Abstrak: Tujuan penelitian ini adalah mengetahui penguasaan konsep siswa pada materi fluida statis dalam pembelajaran STEM disertai e-formative assessment. Penelitian menggunakan mixed method desain embedded experimental. Penelitian melibatkan 30 siswa kelas XI SMA di Sidoarjo. Instrumen pretest dan posttest berupa 10 soal penguasaan konsep pilihan ganda disertai alasan dengan reliabilitas 0,629 . Hasil uji Wilcoxon sebesar $p=.000$ dengan rata-rata posttest lebih tinggi daripada pretest menunjukkan bahwa terdapat perbedaan yang signifikan antara penguasaan konsep siswa sebelum dan sesudah pembelajaran. Nilai effect size sebesar 0,88 menunjukkan bahwa pembelajaran STEM disertai e-formative assessment berpengaruh sedang terhadap penguasaan konsep. Penguasaan konsep siswa setiap indikator juga akan dibahas.
\end{abstract}

\author{
Alamat Korespondensi: \\ Zahrotul Ula Irma \\ Pendidikan Fisika \\ Universitas Negeri Malang \\ Jalan Semarang 5 Malang \\ E-mail: zahrotululairma@gmail.com
}

Fluida statis merupakan materi pelajaran fisika yang konsepnya banyak diterapkan dalam kehidupan sehari-hari. Hal ini membuat siswa perlu untuk menguasai konsep fluida statis dengan baik. Siswa yang menguasai konsep dapat menjelaskan fenomena dalam kehidupan sehari-hari, mengidentifikasi suatu masalah, memilih strategi pemecahan masalah yang tepat, dan merancang suatu proyek (Docktor, Strand, Mestre, \& Ross, 2015; Mason \& Singh, 2016). Penguasaan konsep merupakan tujuan penting dari pembelajaran fisika (Docktor \& Mestre, 2014; Wuttiprom, 2018). Beberapa penelitian menunjukkan bahwa siswa belum menguasai konsep fluida statis dengan baik. Terkait tekanan hidrostatis, siswa menganggap bahwa permukaan area air memengaruhi tekanan hidrostatis (Irwansyah, Sukarmin, \& Harjana, 2018). Ada juga yang menganggap bahwa semakin besar luas permukaan benda yang dimasukkan ke dalam zat cair, semakin besar pula tekanan hidrostatisnya. Selain itu, benda mengalami tekanan hidrostatis ketika berada di tengah kedalaman karena pada posisi ini benda mendapat tekanan dari permukaan dan dasar air (Ammase, Siahaan, \& Fitriani, 2019). Terkait Hukum Pascal, siswa kesulitan untuk menghubungkan konsep tekanan dengan Hukum Pascal (Michelini \& Stefanel, 2019). Hasil penelitian Ammase, et al (2019) menunjukkan bahwa siswa menganggap besar gaya pada salah satu piston sama dengan besar gaya pada piston yang lainnya. Siswa juga menganggap bahwa luas bidang pada piston berbanding terbalik dengan gaya yang dihasilkan pada bidang (Irwansyah et al., 2018). Terkait dengan hukum Archimedes, siswa mengalami kesulitan mengenai gaya apung (Koes-H, Muhardjito, \& Wijaya, 2018; Wagner, Carbone, \& Lindow, 2014), menentukan gaya yang bekerja dan gaya yang dihasilkan benda dalam fluida (Koes$\mathrm{H}$ et al., 2018).

Ada beragam cara yang telah dilakukan untuk membantu siswa menguasai konsep fluida statis. Salah satu cara tersebut melalui demonstrasi laboratorium dan visualisasi komputer (Gynnild, Myrhaug, \& Pettersen, 2007) dan lembar kerja siswa berbasis eksperimen dengan peta konsep (Mujasam, Allo, \& Ansaruddin, 2019). Cara-cara tersebut dapat membantu siswa menguasai konsep fluida statis, namun belum memenuhi standar pembelajaran abad 21 yang diharapkan dapat membekali siswa dengan keterampilan abad 21. Salah satu pembelajaran yang memenuhi standar pembelajaran abad 21 adalah pembelajaran STEM (Science, Technology, Engineering, and Mathematics). Pembelajaran STEM dianggap mampu menyiapkan siswa untuk 
menghadapi abad 21 karena pembelajaran STEM menuntut siswa untuk merekonstruksi pengetahuan, berkolaborasi, memecahkan masalah, belajar melalui perancangan, melakukan konstruksi, dan menggunakan teknologi (Shelley \& Kiray, 2018). Beberapa hasil penelitian telah menunjukkan bahwa pembelajaran STEM berhasil melatihkan keterampilan 21 (Lou, Shih, Ray Diez, \& Tseng, 2011; Shelley \& Kiray, 2018; Tseng, Chang, Lou, \& Chen, 2013). Namun, belum ada penelitian yang membahas penguasaan konsep siswa dalam pembelajaran STEM atau hasil penelitian yang menunjukkan bahwa pembelajaran STEM dapat membantu siswa menguasai konsep dengan baik. Oleh karena itu, peneliti tertarik untuk meneliti penguasaan konsep siswa dalam pembelajaran STEM.

Alur pembelajaran STEM bergantung pada fokus masalah. Ada beberapa jenis STEM berdasarkan fokus masalah, salah satunya yaitu STEM berbasis proyek. Pada pembelajaran STEM berbasis proyek, siswa diberikan spesifikasi yang diinginkan untuk produk akhir dan guru berperan sebagai pelatih ahli yang memberikan panduan dan saran untuk cara yang lebih efektif dalam mencapai produk akhir (Asghar, Ellington, Rice, Johnson, \& Prime, 2012). Pembelajaran yang menghasilkan suatu proyek membutuhkan waktu yang lebih banyak (Green, Allan, \& Crough, 2019). Hal ini memungkinkan siswa kurang fokus dalam menguasai konsep secara mendalam atau hanya menguasai konsep-konsep yang terkait dengan proyek tersebut. Salah satu cara membantu siswa menguasai konsep dengan baik dalam pembelajaran STEM berbasis proyek adalah dengan menyertakan formative assessment (penilaian formatif). Selama melakukan formative assessment, guru dan siswa menggali informasi terkait kesulitan belajar siswa, lalu menggunakan informasi tersebut untuk memberikan bantuan yang tepat dan sesuai dengan kebutuhan siswa (Dufresne \& Gerace, 2004). Pemberian bantuan yang sesuai dalam formative assessment disebut feedback. Feedback yang tepat akan membantu siswa dalam proses pembelajaran (Dahalan \& Hussain, 2010). Akan tetapi, penerapan formative assessment di dalam kelas membutuhkan waktu yang lama.

Solusi dari permasalahan ini adalah dengan menggunakan e-formative assessment. Menurut Dahalan \& Hussain (2010), e-formative assessment dapat mengatasi masalah formative assessment yang membutuhkan waktu lama. E-formative assessment dapat digunakan untuk mengevaluasi penguasaan konsep siswa (Wang, Wang, Wang, \& Huang, 2006), dan meningkatkan kinerja belajar siswa (Buchanan, 2001). E-formative assessment memungkinkan semakin banyaknya interaksi dan dukungan belajar yang menjadikan pembelajaran lebih efisien (Köse, 2010). Pembelajaran online juga mampu meningkatkan kualitas dalam pembelajaran face to face. Melalui cara memaksimalkan waktu pembelajaran di kelas untuk pemecahan masalah dan penguasaan konsep yang mendalam mampu membuat pembelajaran lebih aktif dan memaksimalkan penguasaan konsep siswa (Bazelais \& Doleck, 2018). Lingkungan pembelajaran yang aktif seperti ini dapat meningkatkan kualitas pengajaran dan hasil belajar dalam pendidikan sains (Bazelais \& Doleck, 2018). Mengingat manfaat dari e-formative assessment yang sangat efektif dalam pembelajaran, maka perlu mengintegrasikan e-formative assessment dalam pembelajaran STEM untuk meningkatkan penguasaan konsep siswa pada materi fluida statis.

\section{METODE}

Penelitian ini menggunakan mixed method dengan desain embedded experimental. Penelitian ini melibatkan 30 siswa kelas XI Sekolah Menengah Atas di Sidoarjo. Subjek diberikan perlakuan berupa pembelajaran STEM disertai e-formative assessment. Perlakuan diberikan selama empat pertemuan tatap muka yang didahului dengan kegiatan online.

Kegiatan pertemuan pertama adalah orientasi masalah dan penyelidikan. Sebelum pertemuan pertama siswa diberikan LKS proyek pembuatan miniatur masjid apung, LKS percobaan fluida statis, dan video pembelajaran fluida statis. Pada pertemuan pertama, siswa melakukan percobaan tentang fluida statis. Kegiatan pertemuan kedua adalah penyelidikan dan mendesain. Sebelum pertemuan kedua, siswa diminta mengunggah LKS hasil percobaan, mengerjakan soal formatif, mempelajari video pembelajaran, mencari referensi tentang bangunan apung, dan mencari referensi bentuk masjid. Pada pertemuaan kedua, siswa melakukan diskusi kelas terkait konsep dalam fluida statis, lalu berkumpul dengan kelompok untuk membuat desain miniatur masjid apung. Kegiatan pertemuan ketiga adalah menguji proyek. Sebelum pertemuan ketiga siswa diminta mengerjakan soal formatif dan mengunggah desain miniatur. Pada pertemuan ketiga, setiap kelompok menguji kemampuan mengapung dan daya tampung miniatur masjid apung. Setiap kelompok diberikan feedback dan diberi kesempatan untuk merevisi miniaturnya. Kegiatan pertemuan keempat adalah menguji proyek yang telah direvisi. Sebelum pertemuan keempat, siswa diberikan tes formatif dan diminta mengunggah video pembuatan miniatur. Pada pertemuan keempat, setiap kelompok menguji dan melakukan penilaian ulang terhadap miniatur, setelah itu mengevaluasi proses pembuatan dan hasilnya.

Subjek diberikan pretest sebelum perlakuan dan posttest setelah perlakuan untuk mengukur penguasaan konsep. Instrumen yang digunakan berupa 10 soal pilihan ganda disertai alasan dengan reliabilitas 0,629 dan level kognitif dari C3 sampai C5. Data pretest dan posttest dianalisis menggunakan uji Wilcoxon untuk mengetahui signifikansi perbedaan nilai pretest dan posttest. Uji non parametrik wilcoxon dilakukan karena data pretest dan posttest penguasaan konsep terdistribusi tidak terdistribusi normal. Nilai effect size juga dihitung untuk mengetahui pengaruh pembelajaran STEM disertai $e$-formative assessment. 


\section{HASIL}

Hasil pretest dan posttest penguasaan konsep siswa pada materi fluida statis disajikan dalam tabel 1. Data pada tabel 1 menunjukkan bahwa nilai rata-rata posttest lebih tinggi daripada pretest. Hasil pretest dan postest ini juga diuji beda untuk mengetahui apakah perbedaan tersebut signifikan atau tidak. Oleh karena data pretest dan posttest tidak terdistribusi normal, maka dilakukan uji Wilcoxon. Hasil uji Wilcoxon menunjukkan bahwa rata-rata nilai pretest dan posttest berbeda secara signifikan $(p=.000)$. Adapun besar effect size adalah 0,88. Hasil ini menunjukkan bahwa pembelajaran STEM disertai $e$ formative assessment berpengaruh sedang terhadap peguasaan konsep.

Tabel 1. Statistik Deskriptif Skor Penguasaan Konsep Siswa

\begin{tabular}{cccccc}
\hline & N & Minimum & Maximum & Mean & Std. Deviation \\
\hline Pretest & 30 & 0 & 50 & 22,33 & 13,047 \\
Posttest & 30 & 40 & 90 & 70,67 & 10,483 \\
\hline
\end{tabular}

Penguasaan konsep siswa dapat dilihat berdasarkan persentase penguasaan konsep siswa setiap indikator dalam tabel 2 . Ketika pretest, ada beberapa indikator yang persentasenya $0 \%$. Indikator tersebut adalah indikator 4, 6, 9, dan 10. Setelah diberikan pembelajaran STEM disertai e-formative assessment, persentase indikator 4 dan 10 meningkat tinggi menjadi $90 \%$ dan $67 \%$. Berbeda dengan indikator 6 yang hanya meningkat sebesar 10\%. Bahkan indikator 9 tidak mengalami peningkatan, tetap $0 \%$. Sementara itu, indikator lainnya mengalami peningkatan yang tinggi. Peningkatan indikator 2 termasuk rendah namun ketika pretest persentasenya sudah tinggi, yaitu sebesar $93 \%$ dan ketika posttest persentasenya menjadi $100 \%$.

Tabel 2. Persentase Penguasaan Konsep Siswa pada Setiap Indikator

\begin{tabular}{|c|c|c|c|c|}
\hline \multirow{2}{*}{ No } & \multirow{2}{*}{ Indikator } & \multicolumn{2}{|c|}{ Persentase } & \multirow{2}{*}{ Perbedaan } \\
\hline & & Pretest (\%) & Posttest (\%) & \\
\hline 1 & Menganalisis hubungan antara kedalaman fluida dan tekanan hidrostatik & 7 & 90 & 83 \\
\hline 2 & Menganalisis hubungan antara massa jenis fluida dan tekanan hidrostatik & 93 & 100 & 7 \\
\hline 3 & Menganalisis hubungan antara kedalaman fluida dan massa jenis terhadap tekanan & 17 & 83 & 67 \\
\hline 4 & hidrostatik & 0 & 90 & 90 \\
\hline 5 & Menganalisis tekanan di setiap titik dalam fluida & 20 & 83 & 63 \\
\hline 6 & Menganalisis hubungan antara gaya dan luas pemampang & 0 & 10 & 10 \\
\hline 7 & Membandingkan gaya apung pada balok yang berbeda massanya & 13 & 77 & 63 \\
\hline 8 & Membandingkan gaya apung pada balok yang berbeda volumenya & 3 & 57 & 53 \\
\hline 9 & $\begin{array}{l}\text { Memprediksi bagian benda yang tercelup ketika dimasukkan ke dalam jenis fluida } \\
\text { berbeda }\end{array}$ & 0 & 0 & 0 \\
\hline 10 & $\begin{array}{l}\text { Memprediksi bagian benda tak beraturan yang tercelup ketika posisi benda diubah } \\
\text { Menentukan jenis bahan yang dapat mengapung }\end{array}$ & 0 & 67 & 67 \\
\hline
\end{tabular}

Respons siswa terhadap soal penguasaan konsep juga dikategorikan ke dalam level penguasaan konsep Abraham et al (1994). Alasan yang diberikan siswa dikategorikan ke dalam lima level, yaitu Level 0-No Understanding (NU), level 1-Specific Misconception (SM), level 2-Partial Understanding with a Specific Misconception (PU/SM), level 3-Partial Understanding (PU), dan level 4-Sound Understanding (SU). Soal untuk indikator 9 (memprediksi bagian benda tak beraturan yang tercelup ketika posisi benda diubah) ini ditunjukkan pada gambar 1.

Sebuah balok kayu dengan batu yang diikat di atasnya mengapung di air. Ketika batu berada di atas balok kayu seperti pada gambar, tepat setengah bagian balok kayu terendam di air.

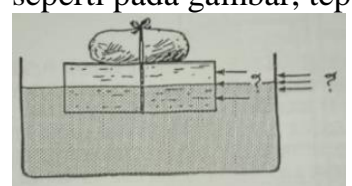

Ketika balok kayu dibalik sehingga batu berada di bawah dan terendam, bagian balok kayu yang terendam adalah ....

A. Semua bagian

B. Lebih dari setengah

C. Tetap setengah

D. Kurang dari setengah

E. Tidak ada bagian yang terendam

Gambar 1. Soal indikator memprediksi bagian benda tak beraturan yang tercelup ketika posisi benda diubah 
Pada soal nomor 9,22 siswa berada pada level 2 (Partial Understanding with a Specific Misconception) sementara delapan sisanya berada pada level 0 (No Understanding) karena tidak memberikan alasan. 22 siswa yang berada pada level 2 memilih jawaban A (semua bagian balok terendam) dengan alasan yang berbeda-beda. Alasan tersebut ditunjukkan sebagaiamana tabel 3 .

Tabel 3. Alasan Siswa Terhadap Soal Penguasaan Konsep Nomor 9

\begin{tabular}{clc}
\hline No & \multicolumn{1}{c}{ Alasan Siswa } & Jumlah Siswa \\
\hline 1 & Gaya berat batu membuat batu dan kayu lebih cepat tenggelam & 6 \\
2 & Gaya berat batu lebih besar dari gaya apung balok kayu & 8 \\
3 & Massa jenis batu lebih besar daripada massa jenis balok kayu & 4 \\
4 & Luas penampang batu lebih kecil dan massa jenisnya lebih besar & 1 \\
& sehingga membuatnya lebih cepat tenggelam & 3 \\
\hline
\end{tabular}

Enam siswa menganggap bahwa kayu akan terendam seluruhnya karena batu lebih berat. Gaya berat batu menarik batu dan kayu ke bawah dan akhirnya tenggelam. Enam siswa ini menyampaikan alasan tersebut karena mereka meyakini setiap batu yang dimasukkan ke air pasti akan tenggelam. Ada delapan siswa membandingkan gaya berat batu dengan gaya apung kayu. Delapan siswa ini menganggap bahwa benda yang berat seperti batu akan tenggelam dan tidak mendapat gaya apung, sementara benda yang ringan seperti kayu akan mengapung dan mendapat gaya apung. Oleh sebab itu, delapan siswa tersebut membandingkan gaya berat batu dan gaya apung balok kayu. Ketika batu di bawah maka gaya berat batu yang lebih menentukan posisi batu dan kayu. Ada juga siswa yang membandingkan massa jenis batu dan massa jenis kayu. Oleh karena batu yang berada di bawah dan massa jenis batu lebih besar daripada massa jenis kayu dan air, maka batu dan kayu akan terendam seluruhnya. Tidak hanya memperhitungkan gaya berat dan massa jenis. Beberapa siswa memperhatikan permukaan batu. Satu siswa menganggap bahwa luas penampang batu yang lebih kecil daripada bagian atasnya (kayu) akan membuat batu dan kayu tenggelam. Tiga siswa lainnya menganggap bahwa benda yang dapat mengapung adalah benda yang permukaannya rata. Ketika batu yang berada di bawah dan permukaan batu tidak rata, maka batu dan kayu akan tenggelam.

Respons jawaban siswa ketika posttest tidak jauh beda dengan pretest. Jawaban yang dipilih juga tetap A. Lima siswa menyampaikan bahwa massa jenis batu yang lebih besar daripada massa jenis kayu dan air membuat batu dan kayu terendam seluruhnya. Menurut siswa, massa jenis batu lebih besar karena gaya berat batu lebih besar daripada gaya angkat yang diakibatkan oleh fluidanya. Satu siswa memberikan alasan terkait gaya berat batu. Oleh karena gaya batu lebih besar maka gaya berat batu ini akan menarik batu dan kayu tenggelam. Ada juga siswa yang membandingkan gaya apung batu dan balok. Gaya apung batu yang lebih kecil daripada gaya apung balok membuat batu dan balok terendam seluruhnya. Gaya apung batu dianggap lebih kecil daripada kayu karena ketika batu dimasukkan ke dalam air batu akan tenggelam, dimana benda yang tenggelam berarti gaya apungnya kecil. Alasan yang paling banyak disebutkan siswa adalah terkait dengan permukaan batu. Enam siswa menjelaskan bahwa permukaan batu yang tidak simetris tidak membantu batu mengapung sehingga batu dan kayu terendam seluruhnya. 11 siswa menjelaskan bahwa permukaan batu yang tidak rata dan luas penampang kecil membuat gaya apungnya kecil sehingga batu dan kayu terendam seluruhnya.

\section{PEMBAHASAN}

Hasil uji statistik menunjukkan bahwa nilai posttest lebih tinggi daripada pretest secara signifikan. Nilai effect size juga menunjukkan bahwa pembelajaran STEM disertai e-formative assessment berpengaruh sedang terhadap penguasaan konsep. Pembelajaran STEM merupakan pembelajaran berbasis masalah. Hasil penelitian Shishigu, Hailu, \& Anibo (2017) menyatakan bahwa pembelajaran berbasis masalah dapat meningkatkan penguasaan konsep siswa. Pembelajaran yang dilakukan melalui masalah memberikan tantangan kepada siswa untuk berpikir lebih dalam. Pembelajaran berbasis masalah membangun konsep yang dimiliki siswa untuk membentuk struktur pengetahuan yang utuh (Prima \& Kaniawati, 2011). Pada penelitian ini, masalah yang diberikan ke siswa adalah dengan merancang dan membuat miniatur. Agar dapat merancang dan membuat miniatur, siswa harus menguasai konsep terlebih dahulu. Siswa diarahkan untuk melakukan percobaan dan melakukan kegiatan penyelidikan untuk menguasai konsep. Hal ini juga menunjukkan bahwa pembelajaran STEM juga berbasis inkuiri. Pembelajaran yang berbasis inkuiri seperti ini juga dapat meningkatkan penguasaan konsep (Prima \& Kaniawati, 2011).

Melalui e-formative assessment, siswa memperoleh materi pembelajaran sebelum pembelajaran dimulai, konten pembelajaran yang diberikan juga lebih lebih banyak. Selain itu, siswa juga diberikan kuis online beberapa kali. Pemberian kesempatan belajar yang luas dapat membantu kesiapan belajar siswa (Lin \& Lai, 2013; Nutan \& Demps, 2014). Rich conversation dalam kelompok selama melakukan penyelidikan dan menyelesaikan masalah juga dapat mengembangkan penguasaan konsep siswa. Hal ini sejalan dengan penelitian Adams \& Wieman (2015); Saab, van Joolingen, \& van HoutWolters (2012); Urhahne, Schanze, Bell, Mansfield, \& Holmes (2010) yang menyatakan bahwa penguasaan konsep siswa lebih tinggi peningkatannya ketika diberikan tugas penyelidikan secara kelompok daripada secara individu. Yin, Tomita, \& Shavelson (2014) juga menyatakan bahwa formative assessment dapat meningkatkan penguasaan konsep. E-formative 
assessment membantu memperbaiki konsep yang salah melalui umpan balik langsung yang diterima (Ediyanti, 2014). Eformative assessment juga dapat membantu penguasaan konsep siswa yang masih rendah (Cruz, Dias, \& Kortemeyer, 2011).

Secara keseluruhan, penelitian ini menunjukkan bahwa peguasaan konsep siswa meningkat setelah diberikan perlakuan berupa pembelajaran STEM disertai e-formative assessment. Namun, tidak pada semua indikator penguasaan konsep. Pada indikator memprediksi bagian benda tak beraturan yang tercelup ketika posisi benda diubah, persentase pretest $0 \%$ dan persentase posttest tetap 0\%. Ketika pretest moyoritas menjawab semua bagian balok kayu tenggelam dan ketika posttest mayoritas juga menjawab semua bagian balok kayu tenggelam dengan alasan balok kayu diletakkan pada permukaan batu yang tidak rata dan luas penampangnya kecil, maka gaya apungnya juga kecil. Alasan ini muncul karena pada saat menguji kemampuan mengapung miniatur masjid apung yang diberi beban, miniatur masjid apung kelompok yang bagian bawahnya tidak rata dan luas penampangnya kecil tidak mampu mengapung dan menahan beban dengan baik. Hal inilah yang membuat siswa tetap pada pemahamannya bahwa bawah pada permukaan batu yang tidak rata dan luas penampangnya kecil, maka gaya apungnya juga kecil. Ternyata fenomena yang terjadi ketika uji proyek sangat memengaruhi penguasaan konsepnya. Hal ini sama dengan yang disampaikan oleh Chandrasegaran, Treagust, \& Mocerino (2007) bahwa kesalahan konsep yang berkaitan dengan pengalaman dalam kehidupan sehari-hari lebih susah dihilangkan.

\section{SIMPULAN}

Hasil uji Wilcoxon sebesar $p=.000$ dengan rata-rata nilai posttest lebih tinggi daripada nilai pretest. Hal ini menunjukkan bahwa terdapat perbedaan yang signifikan pada penguasaan konsep siswa setelah diberikan pembelajaran STEM disertai $e$ formative assessment. Nila effect size sebesar 0,88 menunjukkan bahwa pembelajaran STEM disertai e-formative assessment berpengaruh sedang terhadap penguasaan konsep.

\section{DAFTAR RUJUKAN}

Adams, W. K., \& Wieman, C. E. (2015). Analyzing the Many Skills Involved in Solving Complex Physics Problems. American Journal of Physics, 83(5), 459-467. https://doi.org/10.1119/1.4913923

Ammase, A., Siahaan, P., \& Fitriani, A. (2019). Identification of Junior High School Students' Misconceptions on Solid Matter and Pressure Liquid Substances with Four Tier Test. Journal of Physics: Conference Series, 1157, 022034. https://doi.org/10.1088/1742-6596/1157/2/022034

Asghar, A., Ellington, R., Rice, E., Johnson, F., \& Prime, G. M. (2012). Supporting STEM Education in Secondary Science Contexts. Interdisciplinary Journal of Problem-Based Learning, 6(2). https://doi.org/10.7771/1541-5015.1349

Bazelais, P., \& Doleck, T. (2018). Investigating the Impact of Blended Learning on Academic Performance in a First Semester College Physics Course. Journal of Computers in Education, 5(1), 67-94. https://doi.org/10.1007/s40692-018-0099-8

Buchanan, T. (2001). The Efficacy of a World-Wide Web Mediated Authentic Assessment. Journal of Computer Assisted Learning, 16(3), 193-200. https://doi.org/10.1046/j.1365-2729.2000.00132.x

Chandrasegaran, A. L., Treagust, D. F., \& Mocerino, M. (2007). The Development of a Two-Tier Multiple-Choice Diagnostic Instrument for Evaluating Secondary School Students' Ability to Describe and Explain Chemical Reactions Using Multiple Levels of Representation. Chemistry Education Research and Practice, 8(3), 293-307. https://doi.org/10.1039/B7RP90006F

Cruz, É., Dias, H., \& Kortemeyer, G. (2011). The Effect of Authentic Assessment in Brazilian University Physics Courses. Revista Brasileira de Ensino de Física, 33(4), 4315-4315. https://doi.org/10.1590/S1806-11172011000400016

Dahalan, H. M., \& Hussain, R. M. R. (2010). Development of Web-Based Assessment in Teaching and Learning Management System (e-ATLMS). Procedia - Social and Behavioral Sciences, 9, 244-248. https://doi.org/10.1016/j.sbspro.2010.12.144

Docktor, J. L., \& Mestre, J. P. (2014). Synthesis of Discipline-Based Education Research in Physics. Physical Review Special Topics - Physics Education Research, 10(2). https://doi.org/10.1103/PhysRevSTPER.10.020119

Docktor, J. L., Strand, N. E., Mestre, J. P., \& Ross, B. H. (2015). Conceptual Problem Solving in High School Physics. Physical Review Special Topics - Physics Education Research, 11(2). https://doi.org/10.1103/PhysRevSTPER.11.020106

Dufresne, R. J., \& Gerace, W. J. (2004). Assessing-to-Learn: Authentic Assessment in Physics Instruction. The Physics Teacher, 42(7), 428-433. https://doi.org/10.1119/1.1804662

Green, D., Allan, C. N., \& Crough, J. (2019). What Is the Purpose? Using Blended Learning Designs to Purposefully Focus on Student Engagement, Support and Learning. In C. N. Allan, C. Campbell, \& J. Crough (Eds.). Blended Learning Designs in STEM Higher Education (pp. 35-58). https://doi.org/10.1007/978-981-13-6982-7_3

Gynnild, V., Myrhaug, D., \& Pettersen, B. (2007). Introducing Innovative Approaches to Learning in Fluid Mechanics: A Case Study. European Journal of Engineering Education, 32(5), 503-516. https://doi.org/10.1080/03043790701433137

Irwansyah., Sukarmin., \& Harjana. (2018). Analysis Profile of Student Misconceptions on The Concept of Fluid Based Instrument Three-Tier Test. Journal of Physics: Conference Series, 1097, 012020. https://doi.org/10.1088/17426596/1097/1/012020

Koes. H. S., Muhardjito., \& Wijaya, C. P. (2018). Scaffolding for Solving Problem in Static Fluid: A Case Study. 030028. https://doi.org/10.1063/1.5019519 
Köse, U. (2010). A Blended Learning Model Supported with Web 2.0 Technologies. Procedia - Social and Behavioral Sciences, 2(2), 2794-2802. https://doi.org/10.1016/j.sbspro.2010.03.417

Lin, J.-W., \& Lai, Y.-C. (2013). Online Authentic Assessments with Social Network Awareness. Computers \& Education, 66, 40-53. https://doi.org/10.1016/j.compedu.2013.02.008

Lou, S. J., Shih, R. C., Ray Diez, C., \& Tseng, K. H. (2011). The Impact of Problem-Based Learning Strategies on STEM Knowledge Integration and Attitudes: An Exploratory Study Among Female Taiwanese Senior High School Students. International Journal of Technology and Design Education, 21(2), 195-215. https://doi.org/10.1007/s 10798-010-9114-8

Mason, A., \& Singh, C. (2016). Using Categorization of Problems as an Instructional Tool to Help Introductory Students Learn Physics. Physics Education, 51(2), 025009. https://doi.org/10.1088/0031-9120/51/2/025009

Michelini, M., \& Stefanel, A. (2019). Innovation in Physics Teaching/Learning for the Authentic Success in Introductory Physics for Bio Area Degrees: The Case of Fluids. In M. Pietrocola (Ed.), Upgrading Physics Education to Meet the Needs of Society (pp. 153-168). https://doi.org/10.1007/978-3-319-96163-7_10

Mujasam, M., Allo, A. Y. T., \& Ansaruddin, M. (2019). The Effectiveness of Experiment-Based Student Worksheets with Map Concept in Understanding the Physics Concepts of Static Fluid Materials. Journal of Physics: Conference Series, 1157, 032023. https://doi.org/10.1088/1742-6596/1157/3/032023

Nutan, M. T. H., \& Demps, E. L. (2014). Online Assessments in Pharmaceutical Calculations for Enhancing Feedback and Practice Opportunities. Currents in Pharmacy Teaching and Learning, 6(6), 807-814. https://doi.org/10.1016/j.cptl.2014.07.010

Prima, E. C., \& Kaniawati, I. (2011). Penerapan Model Pembelajaran Problem Based Learning dengan Pendekatan Inkuiri untuk Meningkatkan Keterampilan Proses Sains dan Penguasaan Konsep Elastisitas pada Siswa SMA. Jurnal Pengajaran Matematika dan Ilmu Pengetahuan Alam, 16(1), 179. https://doi.org/10.18269/jpmipa.v16i1.279

Saab, N., van Joolingen, W., \& van Hout-Wolters, B. (2012). Support of the Collaborative Inquiry Learning Process: Influence of Support on Task and Team Regulation. Metacognition and Learning, 7(1), 7-23. https://doi.org/10.1007/s11409-0119068-6

Shishigu, A., Hailu, A., \& Anibo, Z. (2017). Problem-Based Learning and Conceptual Understanding of College Female Students in Physics. Eurasia Journal of Mathematics, Science and Technology Education, 14(1), 145-154. https://doi.org/10.12973/ejmste/78035

Tseng, K.-H., Chang, C.-C., Lou, S.-J., \& Chen, W.-P. (2013). Attitudes Towards Science, Technology, Engineering and Mathematics (STEM) in a Project-Based Learning (PjBL) Environment. International Journal of Technology and Design Education, 23(1), 87-102. https://doi.org/10.1007/s10798-011-9160-x

Urhahne, D., Schanze, S., Bell, T., Mansfield, A., \& Holmes, J. (2010). Role of the Teacher in Computer - Supported Collaborative Inquiry Learning. International Journal of Science Education, 32(2), 221-243. https://doi.org/10.1080/09500690802516967

Wagner, D. J., Carbone, E., \& Lindow, A. (2014). Exploring Student Difficulties with Buoyancy. 2013 Physics Education Research Conference Proceedings, 357-360. https://doi.org/10.1119/perc.2013.pr.077

Wang, K. H., Wang, T. H., Wang, W. L., \& Huang, S. C. (2006). Learning Styles and Authentic Assessment Strategy: Enhancing Student Achievement in Web-Based Learning: Learning Styles and Authentic Assessment Strategy. Journal of Computer Assisted Learning, 22(3), 207-217. https://doi.org/10.1111/j.1365-2729.2006.00166.x

Wuttiprom, S. (2018). A Comparison of Students' Understanding of Concepts in Fluid Mechanics through Peer Instruction and the T5 Learning Model. 16.

Yin, Y., Tomita, M. K., \& Shavelson, R. J. (2014). Using Formal Embedded Authentic Assessments Aligned with a Short-Term Learning Progression to Promote Conceptual Change and Achievement in Science. International Journal of Science Education, 36(4), 531-552. https://doi.org/10.1080/09500693.2013.787556 